\title{
Phorbol Ester Binding and Protein Kinase C Activity in Normal and Transformed Human Keratinocytes
}

\author{
G. T. SNOEK, ${ }^{1}$ J. BOONSTRA, ${ }^{*}$ M. PONEC, ${ }^{\dagger}$ and S. W. de LAAT \\ Hubrecht Laboratorium, Netherlands Institute of Developmental Biology, Utrecht; \\ * Department of Molecular Cell Biology, University of Utrecht, Utrecht, \\ $\dagger$ Department of Dermatology, University Hospital, \\ Leiden, The Netherlands
}

\begin{abstract}
Normal keratinocytes, SV40-transformed keratinocytes $\left(\mathrm{SVK}_{14}\right)$, and various squamous carcinoma cell (SCC) lines have been used as an in vitro model system to study the properties of phorbol ester receptor and protein kinase $\mathrm{C}$ expression during keratinocyte differentiation. The cell lines used exhibit a decreasing capacity to differentiate in the order of keratinocytes $\sim \mathrm{SVK}_{14}>\mathrm{SCC}-12 \mathrm{~F} 2>\mathrm{SCC}-15>\mathrm{SCC}-4$; moreover, all cell lines respond to a low external $\mathrm{Ca}^{2+}$ concentration by a decreased capacity to differentiate. Normal keratinocytes exhibited the highest number of phorbol ester receptors as compared to the other cell lines, while each individual cell line exhibited a higher number of phorbol ester receptors during growth under normal $\mathrm{Ca}^{2+}$ conditions as compared to cells grown under low $\mathrm{Ca}^{2+}$ conditions. The apparent dissociation constant $\left(K_{d}\right)$ demonstrated only small variations in the various cell lines. In contrast, the cytoplasmic protein kinase $C$ activity, was found to be higher in cells grown under low $\mathrm{Ca}^{2+}$ conditions than in cells grown under normal $\mathrm{Ca}^{2+}$ conditions, indicating the absence of a causal relationship between cytoplasmic protein kinase $\mathrm{C}$ activity and phorbol ester receptor expression. Therefore the properties of protein kinase $\mathrm{C}$ have been determined in more detail in normal keratinocytes and SCC -15 cells. These studies revealed differences between protein kinase $C$ properties from the two cell lines grown under normal and low $\mathrm{Ca}^{2+}$ conditions. The differences included the effect of phorbol 12-myristate 13-acetate (PMA) on the redistribution pattern of protein kinase $C$ between the cytoplasmic and particulate fractions as well as the activating effect of diolein in vitro on protein kinase $\mathrm{C}$ activity, partly purified from particulate or cytoplasmic fractions. These observations demonstrate that the functional protein kinase $C$ activity of keratinocytes is determined by various endogenous and exogenous activators and that these activators are modulated differently in various cell lines, under various growth conditions (low $\mathrm{Ca}^{2+}$ versus normal $\mathrm{Ca}^{2+}$ ). (C) 1987 Academic Press, Inc.
\end{abstract}

Mouse skin has been a main tool in the investigation of the tumor promoting activity of, in particular, the phorbol esters during multiple-stage carcinogenesis [1]. In addition to being well known as tumor promoters, these plant-derived cyclic diterpene compounds are known to modulate cellular differentiation and/or proliferation in a variety of cells and tissues (reviewed in [2]). The effects of phorbol esters on cellular differentiation are of particular interest since the regulation of cellular differentiation may be more important than the control of proliferation during the development of neoplasia. In skin, in contrast to many other tissues or organs, all three effects of phorbol esters have been demonstrated: tumor promotion, induction of terminal differentiation, and stimulation of cellular proliferation [3-5]. A heterogeneous response is observed often in kera-

${ }^{1}$ To whom reprint requests should be sent at Hubrecht Laboratory, Uppsalalaan 8, 3584 CT Utrecht, The Netherlands. 
tinocytes: a subpopulation of cells is induced to proliferate and another subpopulation is induced to differentiate [6-8]. It has been suggested that the state of differentiation of epidermal cells at the time of phorbol ester exposure determines whether the ultimate cellular response will be in a proliferative or a differentiative pathway.

The mechanism by which phorbol esters and other tumor promoters modulate the differentiation and proliferation of keratinocytes is not understood yet. Binding of phorbol esters to specific receptors is an essential event during tumor promotion and affection of cellular differentiation. The specific phorbol ester receptor has been identified as a $\mathrm{Ca}^{2+}$-activated, phospholipid-dependent protein kinase (protein kinase C) (reviewed in [9]). In nonstimulated cells protein kinase $\mathrm{C}$ is located in the cytoplasm in an inactive form; upon stimulation of the cells protein kinase $\mathrm{C}$ is associated with the phospholipids in the plasma membrane and activated. An endogenous activator of protein kinase $\mathrm{C}$ is diacylglycerol (DAG), a compound that is transiently produced in the plasma membrane during ligand-receptor binding-induced signal transduction, as a product of phosphoinositide hydrolysis $[10,11]$. The effects of phorbol 12-myristate 13-acetate (PMA, the most potent phorbol ester) and DAG are twofold: the affinity of protein kinase $\mathrm{C}$ for both $\mathrm{Ca}^{2+}$ and phospholipids is increased. As a result, the enzyme is fully activated at physiological $\mathrm{Ca}^{2+}$ concentrations.

Because of the effects of phorbol esters on the terminal differentiation of human keratinocytes, we have been interested in the expression of phorbol ester receptors and cellular protein kinase $\mathrm{C}$ activity during differentiation. Cultivating human keratinocytes in low $(0.05-0.1 \mathrm{mM})$ calcium results in a decreased capacity of the cells to differentiate, while this capacity is increased upon addition of calcium [12-14]. Earlier studies have demonstrated that the expression of several transmembrane receptors is changed in the differentiated cells. For example, the expression of the receptor for low-density lipoprotein (LDL) and the receptor for epidermal growth factor (EGF) is decreased in differentiated keratinocytes [15, 16]. We have used squamous carcinoma cells (SCC), which are defective in their capacity for $\mathrm{Ca}^{2+}$-induced differentiation [17], in addition to normal keratinocytes and SV40-transformed keratinocytes [18] to study the effect of calcium-induced differentiation upon the expression of the phorbol ester receptors and on protein kinase $\mathrm{C}$ activity. $\mathrm{Ca}^{2+}$ and $\mathrm{EGF}$ have been indicated as the major modulators in keratinocyte proliferation and differentiation $[16,19,20]$. Since phorbol esters inhibit EGF binding by phosphorylation of the EGF receptor [21-23], we have investigated also the effect of PMA on the EGF binding.

\section{MATERIALS AND METHODS}

Cell lines and culture conditions. Juvenile human epidermal keratinocytes were cultured using the Rheinwald-Green feeder layer technique. The SV40-transformed keratinocytes $\left(\mathrm{SVK}_{14}\right)$ were kindly provided by Dr. J. Taylor-Papadimitriou and human squamous carcinoma cell (SCC) lines by Dr. J. Rheinwald. The cells were cultured in a mixture of Dulbecco-Vogt and Ham's F12 medium (3:1) supplemented with $5 \%$ fetal calf serum (FCS), $0.4 \mu \mathrm{g} / \mathrm{ml}$ hydrocortisone, $10^{-6} M$ isoproterenol (normal and SV40-transformed keratinocytes), and $10 \mathrm{ng} / \mathrm{ml} \mathrm{EGF} \mathrm{(normal} \mathrm{keratinocytes).} \mathrm{For} \mathrm{the}$ low-calcium cultures calcium-free Dulbecco-Vogt medium mixed with standard Ham's F12 medium 
(3:1) and supplemented with 5\% Chelex-treated FCS was used. The final calcium concentration was $0.06 \mathrm{~m} M$, as determined by flame photometry.

Phorbol dibutyrate binding. Confluent monolayers of cells were washed twice with phosphatebuffered saline (PBS), and Hepes-buffered DMEM containing $0.1 \%$ bovine serum albumin (BSA) was added. Phorbol ester binding was performed in duplicate by adding $40,000 \mathrm{cpm}\left[{ }^{3} \mathrm{H}\right]$ phorbol dibutyrate $(\mathrm{PDBu})$ per $200 \mu \mathrm{l}$ DMEM $([\mathrm{PDBu}]=16 \mathrm{n} M) .\left[{ }^{3} \mathrm{H}\right] \mathrm{PDBu}$ binding was measured in the presence of 10 , $20,40,80,120$, or $160 \mathrm{n} M$ unlabeled PDBu.

Nonspecific binding was determined in the presence of $20 \mu M \mathrm{PDBu}$ and yielded an average value of $25 \%$. The incubation was carried out for $60 \mathrm{~min}$ at room temperature. The cells were washed five times with icecold PBS and, before liquid scintillation counting, the cells were scraped off and solubilized in $0.5 \mathrm{M} \mathrm{NaOH}$.

Scatchard analysis was performed using the LIGAND program written and described by Munson and Rodbard [24].

Protein kinase $\mathrm{C}$ assay. The $\mathrm{Ca}^{2+}$ - and phospholipid-dependent protein kinase (protein kinase $\mathrm{C}$ ) activity was determined after partial purification of cell lysates. Monolayers were washed twice with $\mathrm{Ca}^{2+}, \mathrm{Mg}^{2+}$-free PBS and scraped into the same buffer containing $8 \mathrm{~m} M$ EGTA. The cells were collected by centrifugation and resuspended in lysis buffer $(20 \mathrm{~m} M$ Tris, pH 7.5, $2 \mathrm{~m} M$ EDTA, 0.5 $\mathrm{m} M$ EGTA, $330 \mathrm{~m} M$ sucrose, $2 \mathrm{~m} M$ phenylmethylsulfonyl fluoride (PMSF), $5 \mathrm{~m} M \beta$-mercaptoethanol) and homogenized by 20 strokes in a Dounce homogenizer. The $10000 \mathrm{~g}$ supernatant was centrifuged for $1 \mathrm{~h}$ at $105,000 \mathrm{~g}$. The $105,000 \mathrm{~g}$ supernatant was passed over a DEAE (DE52) column, equilibrated in lysis buffer. The protein kinase $\mathrm{C}$-containing fraction was removed from the column with lysis buffer containing $0.2 \mathrm{M} \mathrm{NaCl}$. Fatty acid-free BSA was added to the sample to a concentration of $2 \mathrm{mg} / \mathrm{ml}$ and the samples were kept for at least $20 \mathrm{~h}$ at $4^{\circ} \mathrm{C}$ before the protein kinase $\mathrm{C}$ activity was assayed.

The particulate protein kinase $C$ activity was extracted from the combined $10,000 \mathrm{~g}$ and $105,000 \mathrm{~g}$ pellets with lysis buffer containing $1 \%$ Nonidet-P40 and purified as described for the $105,000 \mathrm{~g}$ supernatant.

The $\mathrm{Ca}^{2+}$ - and phospholipid-dependent protein kinase $\mathrm{C}$ activity was assayed by adding $2.5-5 \mu \mathrm{g}$ of cell lysate protein to a reaction mixture (final volume $125 \mu \mathrm{l}$ ) containing $200 \mu \mathrm{g} / \mathrm{ml}$ histone IIIs, 96 $\mu \mathrm{g} / \mathrm{ml}$ phosphatidylserine (PS), and $1 \mathrm{mMCaCl}$, in the presence or absence of $3.2 \mu \mathrm{g} / \mathrm{ml} \mathrm{diolein}$ as indicated. The control values were determined in the same reaction mixture in the presence of PS or $\mathrm{CaCl}_{2}$, or $1 \mathrm{mM}$ EGTA. These measurements indicated the absence of calcium-dependent or phospholipid-dependent kinase activities. The mixtures were preincubated for $5 \mathrm{~min}$ at $30^{\circ} \mathrm{C}$, and the reaction was started by the addition of ATP and $\left[\gamma-{ }^{32} \mathrm{P}\right]$ ATP $\left(10 \mu M, 2 \times 10^{6} \mathrm{cpm} /\right.$ incubation $)$ and allowed to proceed at $30^{\circ} \mathrm{C}$ for $5 \mathrm{~min}$. The reaction was stopped by adding $1 \mathrm{ml}$ ice-cold $25 \%$ TCA to the reaction mixture. The precipitated protein was collected on a Millipore filter $(0.45 \mu \mathrm{m})$ and washed five times with $3 \mathrm{ml}$ ice-cold $10 \%$ TCA containing $10 \mathrm{mM}$ sodium pyrophosphate. The standard error of the mean of the measurements was on average $10 \%$.

$P M A$ distribution in cell fractions. Cells were incubated with $1 \mu \mathrm{Ci}\left[{ }^{3} \mathrm{H}\right] \mathrm{PMA}(10 \mathrm{Ci} / \mathrm{mmol})+10$ $\mathrm{ng} / \mathrm{ml}$ unlabeled PMA for $20 \mathrm{~min}$ at $37^{\circ} \mathrm{C}$ in Hepes-buffered DMEM containing $0.1 \%$ BSA. The cells were treated as described for the protein kinase $C$ assay and during each step the ${ }^{3}[\mathrm{H}]$-content of the fraction was determined.

$E G F$ binding. The binding assay buffer consisted of DMEM containing Hepes (25 $\mathrm{mM}$ ) and $0.1 \%$ BSA. Confluent cell monolayers were incubated with ${ }^{125}$ I-EGF $\left(1.67 \times 10^{-10} \mathrm{M}, 250,000 \mathrm{cpm}, \mathrm{NEN}\right)$ with or without PMA preincubation $(100 \mathrm{ng} / \mathrm{ml})$ in $1 \mathrm{ml}$ binding buffer for $2 \mathrm{~h}$ at room temperature. The mixture was aspirated and the dishes were washed five times with ice-cold PBS. Cells were solubilized in $0.5 \mathrm{M} \mathrm{NaOH}$ and radioactivity was measured. Nonspecific binding was determined by measuring the radioactivity bound in the presence of a large excess (200-fold) of unlabeled EGF.

Materials. Phorbol esters (PDBu, PMA), histones (IIIs from calf thymus), and diolein were purchased from Sigma. PS was from Lipid Products (Surrey, UK). [ $\left.{ }^{3} \mathrm{H}\right] \mathrm{PMA}$ and $\left.{ }^{3} \mathrm{H}\right] \mathrm{PDBu}$ were from NEN, and $\left[\gamma_{-}{ }^{32} \mathrm{P}\right]-\mathrm{ATP}$ was from Amersham (UK).

\section{RESULTS}

\section{PDBu Binding}

PDBu binding was performed at room temperature in monolayer cultures of normal keratinocytes, SV40-transformed keratinocytes, and the squamous carcinoma cell lines SCC-12F2, SCC-15, and SCC-4 as described under Materials and 


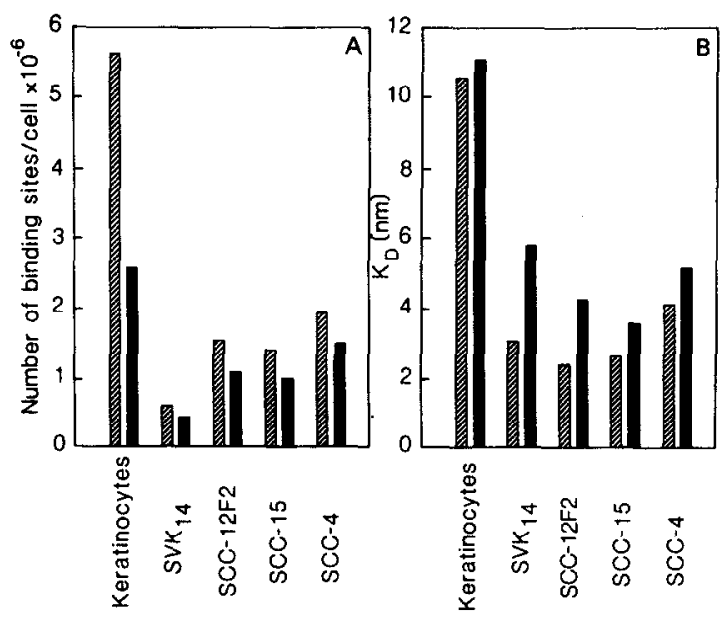

Fig. 1. Effect of external $\mathrm{Ca}^{2+}$ concentrations on total number of phorbol ester receptors $(A)$ and receptor affinity $(B)$. Cells were grown under normal $(1.6 \mathrm{mM}$, striped bars) or low $(0.06 \mathrm{~m} M$, black bars) external $\mathrm{Ca}^{2+}$ concentrations as described under Materials and Methods. The total number of phorbol ester receptors and the affinity were obtained from Scatchard analysis. The Scatchard analysis was based on four different experiments.

Methods. Since no specific PDBu binding was observed in the absence of $\mathrm{Ca}^{2+}$, the binding assay was performed in the presence of $1 \mathrm{mM} \mathrm{Ca}{ }^{2+}$ under all conditions. A steady state of PDBu binding was obtained within 60 min of incubation in the presence of various external concentrations of PDBu in all cell lines (unpublished data). Subsequently, the concentration dependency of PDBu binding was determined and the data were subjected to Scatchard analysis using the LIGAND computer program [24]. A best fit through the data points revealed one class of $\mathrm{PDBu}$ binding sites in all cell lines, suggesting the presence of only one class of PDBu receptors. As shown in Fig. 1, culturing the cells under low $\mathrm{Ca}^{2+}$ conditions resulted in a decrease in the number of PDBu binding sites in all cell lines as compared to cells cultured under normal $\mathrm{Ca}^{2+}$. This difference was most striking in normal keratinocytes in which the total receptor number decreased from $5.6 \times 10^{6}$ binding sites/cell under normal $\mathrm{Ca}^{2+}$ conditions to $2.6 \times 10^{6}$ binding sites/cell under low $\mathrm{Ca}^{2+}$ conditions (Fig. $1 A$ ).

Little variation was observed in receptor affinity (Fig. 1B), although the affinity was relatively low in normal keratinocytes under both normal and low $\mathrm{Ca}^{2+}$ conditions as compared to the other cell lines. Furthermore, in all cell lines the affinity appeared to be slightly higher under normal $\mathrm{Ca}^{2+}$ conditions than under low $\mathrm{Ca}^{2+}$ conditions (Fig. $1 B$ ).

\section{Cytoplasmic Protein Kinase C Activity}

Since a $\mathrm{Ca}^{2+}$ - and phospholipid-dependent protein kinase (protein kinase $\mathrm{C}$ ) is considered to represent the phorbol ester receptor, the cytoplasmic activity of protein kinase $\mathrm{C}$ has been determined in all cell lines cultured under both normal and low $\mathrm{Ca}^{2+}$ conditions (Fig. 2). In general, cytoplasmic protein kinase $\mathrm{C}$ activity was higher in low- $\mathrm{Ca}^{2+}$-cultured cells than in cells grown under normal 


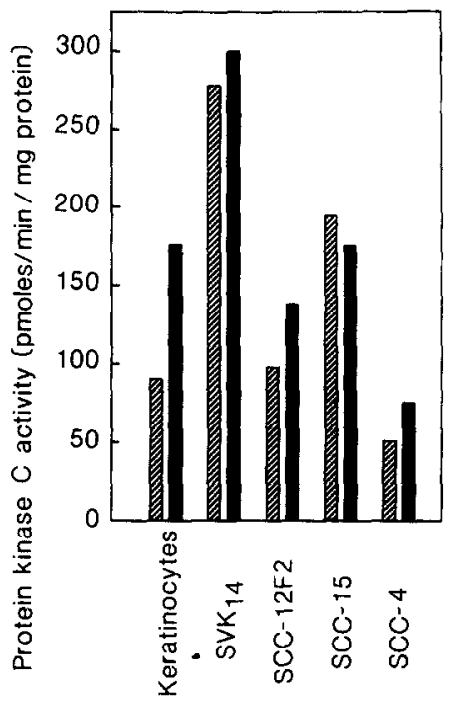

Fig. 2. Effect of external $\mathrm{Ca}^{2+}$ concentrations on cytoplasmic protein kinase $\mathrm{C}$ activity. Cells were grown under normal (1.6 $\mathrm{mM}$, striped bars) or low $\left(0.06 \mathrm{mM}\right.$, black bars) $\mathrm{Ca}^{2+}$ concentrations as described under Materials and Methods. The specific protein kinase $\mathrm{C}$ activity was measured in the presence of PS, $\mathrm{Ca}^{2+}$, and diolein as described under Materials and Methods and is expressed as picomoles ${ }^{32} \mathrm{P}$ incorporated in histones per minute per milligram cellular protein. Each value represents the mean of three experiments.

$\mathrm{Ca}^{2+}$ conditions, except for SCC-15. However, in contrast to EGF binding [16] and LDL binding [15], no clear correlation was observed between cytoplasmic protein kinase $C$ activity and the differentiation capacity of the cell lines. Furthermore, no correlation was found between the number of phorbol ester binding sites and cytoplasmic protein kinase $C$ activity (Figs. $1 A$ and 2). Binding of phorbol esters to cells is known to be accompanied by association of protein kinase $C$ with the plasma membrane. Therefore, it would be more appropriate to correlate phorbol ester binding with plasma membrane-associated protein kinase C activity.

\section{PMA-Induced Redistribution of Protein Kinase C Activity}

The plasma membrane association of protein kinase $C$ might be influenced by exogenous factors and the physicochemical properties of the plasma membrane. For that reason, the effects of PMA on the redistribution pattern of protein kinase $\mathrm{C}$ activity between the cytoplasmic and particulate fractions in two cell lines, normal keratinocytes and SCC-15 cells, cultured under both normal and low $\mathrm{Ca}^{2+}$ conditions, were studied. The redistribution pattern is established by measuring protein kinase $\mathrm{C}$ activity in the absence of diolein.

Incubation of normal keratinocytes and SCC-15 cells, grown under both normal and low $\mathrm{Ca}^{2+}$ concentrations in the presence of $50 \mathrm{ng} / \mathrm{ml}$ PMA for $30 \mathrm{~min}$, induced redistribution of protein kinase $C$ from the cytoplasmic to the particulate fraction in both cell types. The relative protein kinase $\mathrm{C}$ activity in both cytoplasmic and particulate fractions in shown in Fig. 3. 


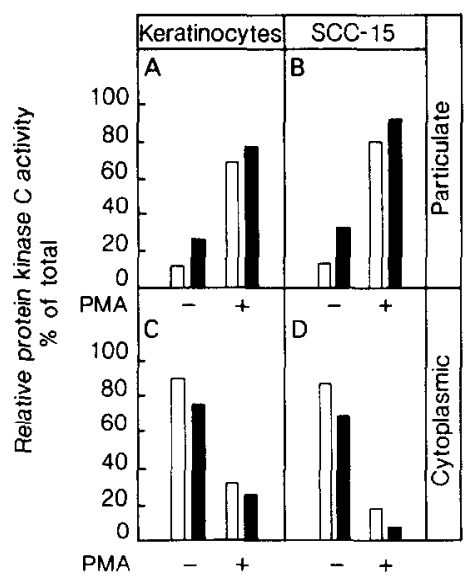

Fig. 3. Effect of external $\mathrm{Ca}^{2+}$ on the relative phorbol ester-induced relocalization of protein kinase $\mathrm{C}$ from cytoplasmic to particulate fractions in normal keratinocytes and SCC-15 cells. Growth conditions were as described under Materials and Methods. Cells were incubated with PMA (50 $\mathrm{ng} / \mathrm{ml}$ ) for $30 \mathrm{~min}$ at $37^{\circ} \mathrm{C}$ in Hepes-buffered DMEM medium containing $0.1 \%$ BSA before lysis and further preparation for protein kinase $\mathrm{C}$ assay. Protein kinase $\mathrm{C}$ activity was measured as described under Materials and Methods in the absence of diolein. Cells were grown under normal $(1.6 \mathrm{mM}$, open bars) or low ( $0.06 \mathrm{mM}$, black bars) $\mathrm{Ca}^{2+}$ concentrations.

An increase in protein kinase $\mathrm{C}$ activity upon incubation with PMA is shown in the particulate fractions of both cell lines under both normal and low $\mathrm{Ca}^{2+}$ conditions, although this effect is more pronounced in SSC-15 cells than in normal keratinocytes (Figs. $3 A$ and $3 B$, Table 1). The relative amount of protein kinase $C$ in the particulate fraction in the absence of PMA appears to be lower in cells cultured under normal calcium conditions than in cells cultured under low $\mathrm{Ca}^{2+}$ conditions [12-27\% for normal keratinocytes (Fig. $3 \mathrm{~A}$ ) and $14-32 \%$ for SCC15 (Fig. $3 B$ )]. The process of redistribution from the cytoplasm to the particulate fraction appears to be more efficient in cells grown under low $\mathrm{Ca}^{2+}$ conditions (76 and $94 \%$ for keratinocytes and SSC-15 respectively) than in cells cultured under normal $\mathrm{Ca}^{2+}$ conditions ( 70 and $83 \%$ for keratinocytes and SCC- 15 , respectively), although the differences are not significant. The results presented in Fig. 3 and Table 1 indicate differences in the redistribution behavior of protein kinase $\mathrm{C}$ between the two cell lines under normal and low $\mathrm{Ca}^{2+}$ conditions.

\section{Effect of Diolein}

The apparent contradiction between PDBu binding sites and cytoplasmic and membrane-associated protein kinase $\mathrm{C}$ activity suggests additional regulatory factors in both protein kinase $\mathrm{C}$ activity and PDBu binding. Such factors could be related to the immediate membrane environment of protein kinase $\mathrm{C}$, as, for example, the endogenous activator diacylglycerol. Diolein has been demonstrated to have differential activating effects on protein kinase $\mathrm{C}$ in cytoplasmic or particulate fractions isolated from various cell types (manuscript in preparation). We measured the potentiating effect of diolein on the PS-dependent activation of 
TABLE 1

Specific activity of protein kinase $C$ (picomoles ${ }^{32} P$ incorporated in histone per minute per milligram protein) in cytoplasmic and particulate fractions of normal keratinocytes and SSC-15 cells grown under normal or low $\mathrm{Ca}^{2+}$ conditions

\begin{tabular}{lccccc}
\hline & \multicolumn{2}{c}{ Cytoplasmic } & & \multicolumn{2}{c}{ Particulate } \\
\cline { 5 - 6 } & Normal $\mathrm{Ca}^{2+}$ & Low $\mathrm{Ca}^{2+}$ & & Normal $\mathrm{Ca}^{2+}$ & $\mathrm{Low} \mathrm{Ca}^{2+}$ \\
\hline Normal keratinocytes & & & & & \\
-PMA & 41 & 90 & & 28 & 42 \\
+PMA & 9 & 30 & & 52 & 93 \\
SCC-15 & & & & 35 \\
-PMA & 150 & 60 & & 45 & 35 \\
+PMA & 41 & 25 & 278 & 260 \\
\hline
\end{tabular}

Note. Cells were incubated with PMA $(50 \mathrm{ng} / \mathrm{ml})$ for $30 \mathrm{~min}$ at $37^{\circ} \mathrm{C}$. Growth conditions, preparation of cytoplasmic and particulate fractions, and assay of protein kinase $\mathrm{C}$ activity were as described under Materials and Methods in the absence of diolein. Each value represents the mean of three experiments.

protein kinase $\mathrm{C}$ isolated from cytoplasmic and particulate fractions of normal keratinocytes and SCC-15 cells grown under both normal and low $\mathrm{Ca}^{2+}$ conditions. During the partial purification procedure of the cellular fractions, all PMA is removed from the protein kinase $\mathrm{C}$-containing preparation. After incubation of the cells with $\left[{ }^{3} \mathrm{H}\right] \mathrm{PMA}$ and fractionation as described for the protein kinase $\mathrm{C}$ assay procedure, the crude cytoplasmic fraction does not contain any $\left[{ }^{3} \mathrm{H}\right] \mathrm{PMA}$, in contrast with the crude particulate fraction. However, after solubilization of the particulate protein kinase $\mathrm{C}$ with $1 \%$ Nonidet-P40, followed by DEAEchromatography, all $\left[{ }^{3} \mathrm{H}\right] \mathrm{PMA}$ is removed from the particulate fraction as well.

(1) Comparison of normal keratinocytes and SSC-15, cytoplasmic and particulate fractions. The effect of diolein on protein kinase $\mathrm{C}$ activity has been measured in the presence of $0.5-1 \mathrm{mM} \mathrm{Ca}{ }^{2+}$ and PS. Addition of diolein results in a stimulation of protein kinase $\mathrm{C}$ activity under all conditions in both particulate and cytoplasmic fractions isolated from both cell lines. Furthermore, as shown in Table 2, protein kinase $\mathrm{C}$ activity in the particulate fractions from normal keratinocytes and SCC-15, grown under normal $\mathrm{Ca}^{2+}$ conditions, can be stimulated by diolein to a significantly higher level than that isolated from the cytoplasmic fraction in these cells. In this respect it is of interest that the particulate protein kinase $\mathrm{C}$ activity in normal keratinocytes grown in normal $\mathrm{Ca}^{2+}$ is stimulated by diolein to a higher level than that in SCC-15 cells (Table 2). On the other hand, we found no differences in stimulation by diolein between particulate and cytoplasmic protein kinase $\mathrm{C}$ from both normal keratinocytes and SCC-15 grown under low $\mathrm{Ca}^{2+}$ conditions (Table 2). 
TABLE 2

$\mathrm{Ca}^{2+}$ and PS-dependent protein kinase activity: Relative stimulation by diolein

\begin{tabular}{|c|c|c|c|c|}
\hline & \multicolumn{2}{|c|}{ Cytoplasmic } & \multicolumn{2}{|c|}{ Particulate } \\
\hline & Normal $\mathrm{Ca}^{2+}$ & Low $\mathrm{Ca}^{2+}$ & Normal $\mathrm{Ca}^{2-}$ & Low $\mathrm{Ca}^{2+}$ \\
\hline \multicolumn{5}{|c|}{ Normal keratinocytes } \\
\hline -PMA & 1.8 & 2.2 & 5.6 & 2.0 \\
\hline$+\mathrm{PMA}$ & 1.9 & 2.8 & 6.3 & 4.6 \\
\hline \multicolumn{5}{|l|}{ SCC-15 } \\
\hline -PMA & 1.3 & 2.9 & 2.7 & 2.5 \\
\hline+ PMA & 1.4 & 2.7 & 2.5 & 1.5 \\
\hline
\end{tabular}

Note. Protein kinase $\mathrm{C}$ was isolated from cytoplasmic and particulate fractions of normal keratinocytes and SCC-15 cells grown under normal or low $\mathrm{Ca}^{2+}$ conditions. Cells were incubated with PMA $(50 \mathrm{ng} / \mathrm{ml})$ for $30 \mathrm{~min}$ at $37^{\circ} \mathrm{C}$. Growth conditions, preparation of cytoplasmic and particulate fractions, and assay of protein kinase $\mathrm{C}$ activity were as described under Materials and Methods. Protein kinase $C$ activity was measured in the presence and absence of diolein.

(2) Comparison of normal keratinocytes and SSC-15 grown under normal and low $\mathrm{Ca}^{2+}$ conditions. Cells grown in low $\mathrm{Ca}^{2+}$ contain relatively more particulate protein kinase $\mathrm{C}$ than do cells grown in normal $\mathrm{Ca}^{2+}$. This has been found in all conditions, i.e., both in normal keratinocytes and in SSC-15, in control and PMAtreated cells (Figs. $3 A$ and $3 B$ ).

A comparison of the activation of protein kinase $C$ by diolein results in the conclusion that cytoplasmic protein kinase $\mathrm{C}$ from cells grown in low $\mathrm{Ca}^{2+}$ is stimulated to a higher level by diolein than is cytoplasmic protein kinase $\mathrm{C}$ isolated from cells grown in normal $\mathrm{Ca}^{2+}$ (Table 2).

In addition, protein kinase $\mathrm{C}$ isolated from the particulate fraction from cells grown under low $\mathrm{Ca}^{2+}$ conditions could not be stimulated to a higher level by diolein when compared to that isolated from the cytoplasmic fraction except for normal keratinocytes prestimulated with PMA (Table 2).

The data presented in Fig. 3 and Table 2 clearly demonstrate differences in PMA-induced redistribution of protein kinase $\mathrm{C}$ activity and in the activation by diolein in vitro of cytoplasmic and particulate protein kinase $\mathrm{C}$ activity in the two cell lines grown under different conditions.

\section{Inhibition of EGF Binding by PMA}

We have measured the inhibition of EGF binding by PMA in normal keratinocytes, in SVK $_{14}$-transformed keratinocytes, and in several SCC lines grown in low and normal $\mathrm{Ca}^{2+}$ (Fig. 4).

Some correlation was found between the number of phorbol ester receptor sites and inhibition of EGF binding, for example, when comparing normal keratinocytes with the SCC lines and cells grown in low and normal $\mathrm{Ca}^{2+}$. No 


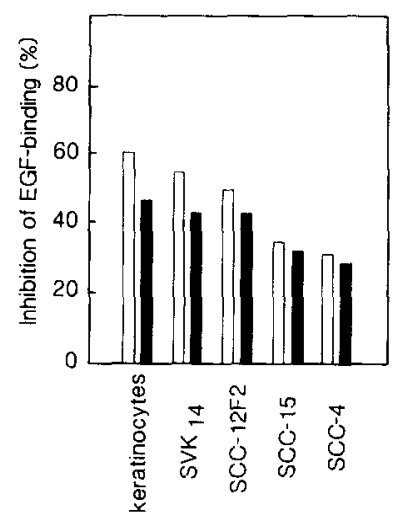

Fig. 4. Effects of external $\mathrm{Ca}^{2+}$ concentration on the PMA-induced inhibition of EGF binding. Cells were grown under normal $\left(1.6 \mathrm{~m} M\right.$, open bars) or low $\left(0.06 \mathrm{mM}\right.$, black bars) $\mathrm{Ca}^{2+}$ concentrations. Cells were preincubated with PMA $(50 \mathrm{ng} / \mathrm{ml})$ for $30 \mathrm{~min}$ at $37^{\circ} \mathrm{C}$ before EGF binding was determined as described under Materials and Methods. Each value represents the mean of two experiments.

correlation was found between inhibition of EGF binding and number of EGF receptors [16] or cytoplasmic protein kinase C (Fig. 2).

\section{DISCUSSION}

The study of the molecular regulation of keratinocyte differentiation has been facilitated by the establishment of various squamous carcinoma cell lines with varying degrees of defects in differentiation capacity in vitro. Using the SCC lines in addition to $\mathrm{SVK}_{14}$ cells and normal keratinocytes, it has been demonstrated that keratinocyte differentiation was accompanied by a decrease in LDL and EGF receptor expression and by modulation of lipid synthesis [15, 16]. Since phorbol esters are known to modulate keratinocyte differentiation and proliferation and, in addition, to interfere with EGF binding and processing, EGF receptor phosphorylation, LDL processing, and lipid synthesis, we studied the properties of phorbol ester binding and protein kinase $C$ activity in the transformed and normal keratinocytes cultured under both normal and low $\mathrm{Ca}^{2+}$ conditions. It is shown that normal keratinocytes contained a high number of phorbol ester receptors as compared to the transformed cell lines. Furthermore, lowering the external $\mathrm{Ca}^{2+}$ concentration, thereby reducing the keratinocyte differentiation capacity, resulted in a decrease in the number of phorbol ester binding sites in all cell lines (Fig. 1).

Protein kinase $\mathrm{C}$ has been shown to be the specific receptor for phorbol esters and it has been demonstrated for several cell types that the amount of protein kinase $\mathrm{C}$ activity parallels the number of phorbol ester binding sites [25]. However, determination of cytoplasmic protein kinase $\mathrm{C}$ activity in the various keratinocyte cell lines, grown under both normal and low $\mathrm{Ca}^{2+}$ conditions, revealed no correlation between phorbol ester binding and protein kinase $\mathrm{C}$ activity. In all cell lines, except for $\mathrm{SCC}-15$, protein kinase $\mathrm{C}$ activity was higher in low- $\mathrm{Ca}^{21}$ - 
cultured cells than in cells cultured under normal $\mathrm{Ca}^{2+}$ conditions, in contrast to the number of phorbol ester binding sites. Determination of the plasma membrane-associated protein kinase $\mathrm{C}$ activity revealed again a discrepancy between phorbol ester binding and protein kinase $\mathrm{C}$ activity.

From these results it must be concluded that the function of protein kinase $\mathrm{C}$ as receptor for phorbol esters is influenced and regulated by other factors, intracellular or membrane-associated. The composition of the plasma membrane is an important factor regulating the association of protein kinase $\mathrm{C}$ with the plasma membrane. It has been demonstrated that the PS/PC ratio in artificial bilayers affects the activation of protein kinase $C$ and the insertion of protein kinase $C$ into the bilayer $[26,27]$. Furthermore, the fatty acid composition of the activating phospholipids has been shown to affect the activation of protein $\mathrm{C}$, both the $\mathrm{Ca}^{2+}$ and phospholipid-dependent protein kinase $\mathrm{C}$ activity, and the effects of DAG or PMA (Snoek et al., submitted). Another aspect of membranes that has been shown to affect the association of protein kinase $C$ with the plasma membrane is the cholesterol content. Manipulation of the cholesterol content of the plasma membrane results in an unchanged cellular protein kinase $\mathrm{C}$ content but induces variations in the PMA-induced redistribution of protein kinase $\mathrm{C}$ and the phorbol ester binding capacity of the cells (unpublished results). The effect of the phospholipid composition of the plasma membrane has been demonstrated by Cabot, who showed that phorbol ester binding to human promyelocytic cells was affected by changes in the phospholipid composition of the plasma membrane [28].

In addition to external regulatory factors, intrinsic variations of protein kinase $\mathrm{C}$ probably have a function in the regulation of its activation. Recently, the sequences of three to six different genes coding for protein kinase $\mathrm{C}$ have been identified $[29,30]$, each giving rise to enzymes with identical molecular weights. As yet the difference between the gene products is not known but it has been suggested that the variations will be found in the $\mathrm{Ca}^{2+}$ binding domain of the protein. In view of the fact that diolein affects the affinity of protein kinase $\mathrm{C}$ for calcium [31], the variation in sensitivity for diolein activation described in the present study may illustrate the presence of several protein kinase $\mathrm{C}$ gene products in cytoplasmic and particulate fractions of normal and $\mathrm{SVK}_{14}$-transformed keratinocytes and the SCC lines.

These observations clearly demonstrate that the functional protein kinase $\mathrm{C}$ activity is determined not only by the number of enzyme copies and the presence of various exogenous activators, but presumably by other parameters as well, such as the composition and physicochemical properties of the membrane or the intrinsic properties of the enzyme itself. The relatively small differences in inhibition of EGF binding by PMA also demonstrate the absence of a direct correlation between number of phorbol ester receptors, the cellular protein kinase $C$ activity, and the number of EGF receptors, indicating another regulatory fact in protein kinase $C$ activation and biochemical or cellular effects: substrate specificity and affinity.

In summary the activation process of protein kinase $\mathrm{C}$ can be regulated by factors outside the enzyme (plasma membrane composition, DAG, phorbol es- 
ters, fatty acid composition, etc.) and in the enzyme itself. Following this theory, it is possible that even when cytoplasmic protein kinase $\mathrm{C}$ is present, in some cell types it is only associated or activated to a certain level at the plasma membrane or available as receptor for exogenous phorbol esters or endogenous DAG.

Keeping in mind the functions of phorbol esters as tumor promoters and inducers/inhibitors of cellular differentiation, it must be concluded that the presence of protein kinase $C$ and phorbol esters is not sufficient to induce the activation process. Regulatory elements as mentioned before will be able to determine the actual level of activation of protein kinase $\mathrm{C}$ by phorbol esters. A comparison of these regulatory elements in cells/tissues where differential effects of phorbol esters are found could shed light on the mechanisms of these processes and the involvement of protein kinase $\mathrm{C}$ in tumor promotion or cellular growth and differentiation.

\section{REFERENCES}

1. Slaga, T. (1983) Cancer Surveys 2, 595.

2. de Laat, S. W., Boonstra, J., Moolenaar, W. H., Mummery, C. L., van der Saag, P. T., and van Zoelen, E. J. J. (1983) in Development of Mammals (Johnson, M. H., Ed.), 5, p. 857, Elsevier, Amsterdam/New York.

3. Parkinson, E. K., Grabham, P., and Emmerson, A. (1983) Carcinogenesis 4, 857.

4. Parkinson, E. K., Pera, M. F., Emmerson A., and Gorman, P. (1984) Carcinogenesis 5, 1071.

5. Reiners, J. J., and Slaga, T. J. (1983) Cell 32, 247.

6. Hawley-Nelson, P., Stanley, J. R., Schmidt, J., Gullino, M., and Yuspa, S. H. (1982) Exp. Cell Res. 137, 155.

7. Mufson, R. A., Steinberg, M. L., and Defendi, V. (1982) Cancer Res. 42, 4600.

8. Willer, J. J., Pittelkow, M. R., and Scott, R. E. (1984) Carcinogenesis 6, 1181.

9. Nishizuka, Y. (1984) Nature (London) 308, 693.

10. Berridge, M. J. (1984) Biochem. J. 220, 345.

11. Hokin, L. E. (1985) Ann. Rev. Biochem. 54, 205.

12. Hawley-Nelson, P., Sullivan, J. E., Kung, M., Hennings, H., and Yuspa, S. H. (1980) J. Invest. Dermatol. 75, 176.

13. Hennings, H., Michael, D., Cheng, C., Steinert, P., Holbrook, K., and Yuspa, S. H. (1980) Cell $19,245$.

14. Hennings, H., Holbrook, K. A., and Yuspa, S. H. (1983) J. Cell Physiol 116, 265.

15. Ponec, M., Havekes, L., Kempenaar, J., Lavrijsen, S., Wijsman, M., Boonstra, J., and Vermeer, B. J. (1985) J. Cell Physiol. 125, 98.

16. Boonstra, J., de Laat, S. W., and Ponec, M. (1985) Exp. Cell Res. 161, 421.

17. Rheinwald, J. G., and Beckett, M. A. (1980) Cell 22, 629.

18. Steinberg, M. I., and Defendi, V. (1979) Proc. Natl. Acad. Sci. USA 76, 801.

19. Malmqvist, K. G., Carlsson, L. E., Forslind, B., and Roomans, G. H. (1984) Nucl. Instrum. Methods Phys. Res. 133, 611.

20. Forslind, B., Roomans, G. M., Carlsson, L. E., Malmqvist, K. G., and Akselsson, K. R. (1984) Scanning Electron Microsc, 2, 755.

21. Magun, B. E., Matrisian, L. M., and Bowden, G. T. (1980) J. Biol. Chem. 255, 6373.

22. Davis, R. J., and Czech, M. P. (1984) J. Biol. Chem. 259, 8545.

23. Cochet, C., Gill, G. N., Meisenfelder, J., Cooper, J. A., and Hunter, T. (1984) J. Biol. Chem. 259, 2553.

24. Munson, P. J., and Rodbard, D. (1980) Anal. Biochem. 107, 220.

25. Snoek, G. T., Mummery, C. L., van den Brink, C. E., van der Saag, P. T., and de Laat, S. W. (1986) Dev. Biol. 115, 282.

26. Blumberg, P. M., Yaken, S., König, B., Sharkey, N. A., Leach, K. L., Jeng, A. Y., and Yek, E. (1984) Biochem. Pharmacol. 33, 933.

27. Snoek, G. T., Rosenberg, I., de Laat, S. W., and Gitler, C. (1986) Biochim. Biophys. Acta 860, 336. 
28. Cabot, M. C. (1983) Cancer Res. 43, 4233.

29. Knopf, J. L., Lee, M. H., Sultzmann, L. A., Kriz, R. A., Loomis, C. R., Hewick, R. M. and Bell, R. M. (1986) Cell 48, 491.

30. Coussens, L., Parker, P. J., Rhee, L., Yang Feng, T. L., Chen, E., Waterfield, M. D., Franke, K., and Ullich, A. (1986) Science 233, 859.

31. Castagna, M., Takai, Y., Kaibuchi, K., Sano, K., Kikkawa, K., and Nishizuka, Y. (1982) J. Biol. Chem. 257, 7847.

Received November 11, 1986

Revised version received March 2, 1987 